\title{
Molybdenum limitation of microbial nitrogen assimilation in aquatic ecosystems and pure cultures
}

\author{
Jennifer B. Glass ${ }^{1}$, Richard P. Axler ${ }^{2}$, Sudeep Chandra ${ }^{3}$ and Charles R. Goldman \\ 1 School of Earth and Space Exploration, Arizona State University, Arizona, AZ, USA \\ ${ }^{2}$ Natural Resources Research Institute, University of Minnesota Duluth, Duluth, MN, USA \\ ${ }^{3}$ Department of Natural Resources and Environmental Science, University of Nevada Reno, Reno, NV, USA \\ ${ }^{4}$ Department of Environmental Science and Policy, University of California Davis, Davis, CA, USA
}

\section{Edited by:}

Sergio Sañudo-Wilhelmy, University of Southern California, USA

\section{Reviewed by:}

Xiu-Lan Chen, Shandong University, China

Douglas G. Capone, University of

Southern California, USA

${ }^{*}$ Correspondence:

Jennifer B. Glass, Division of Geological and Planetary Sciences, California Institute of Technology, MC 100-23, 1200 E. California Blvd., Pasadena, CA 91125, USA.

e-mail: jglass@caltech.edu
Molybdenum (Mo) is an essential micronutrient for biological assimilation of nitrogen gas and nitrate because it is present in the cofactors of nitrogenase and nitrate reductase enzymes. Although $\mathrm{Mo}$ is the most abundant transition metal in seawater $(107 \mathrm{nM})$, it is present in low concentrations in most freshwaters, typically $<20 \mathrm{nM}$. In 1960, it was discovered that primary productivity was limited by Mo scarcity $(2-4 \mathrm{nM})$ in Castle Lake, a small, meso-oligotrophic lake in northern California. Follow up studies demonstrated that Mo also limited primary productivity in lakes in New Zealand, Alaska, and the Sierra Nevada. Research in the 1970s and 1980s showed that Mo limited primary productivity and nitrate uptake in Castle Lake only during periods of the growing season when nitrate concentrations were relatively high because ammonium assimilation does not require Mo. In the years since, research has shifted to investigate whether Mo limitation also occurs in marine and soil environments. Here we review studies of Mo limitation of nitrogen assimilation in natural microbial communities and pure cultures. We also summarize new data showing that the simultaneous addition of Mo and nitrate causes increased activity of proteins involved in nitrogen assimilation in the hypolimnion of Castle Lake when ammonium is scarce. Furthermore, we suggest that meter-scale Mo and oxygen depth profiles from Castle Lake are consistent with the hypothesis that nitrogen-fixing cyanobacteria in freshwater periphyton communities have higher Mo requirements than other microbial communities. Finally, we present topics for future research related to Mo bioavailability through time and with changing oxidation state.

Keywords: molybdenum, nitrate reductase, nitrogen fixation, limnology, trace elements, microbes, nutrient limitation, enzyme activity

\section{INTRODUCTION}

Molybdenum (Mo) is an essential micronutrient in all three domains of life. Mo is particularly important for microbial nitrogen $(\mathrm{N})$ assimilation due to its presence in nitrogenase, the enzyme that performs $\mathrm{N}_{2}$ fixation and in nitrate reductase, the enzyme that performs the first step in nitrate $\left(\mathrm{NO}_{3}^{-}\right)$assimilation, reduction of $\mathrm{NO}_{3}^{-}$to nitrite $\left(\mathrm{NO}_{2}^{-}\right)$. For other biological functions of Mo, see Sigel and Sigel (2002). When ammonium $\left(\mathrm{NH}_{4}^{+}\right)$ is present over a certain threshold, it is either preferred over $\mathrm{NO}_{3}^{-}$ or inhibits $\mathrm{NO}_{3}^{-}$uptake (Dortch, 1990), and Mo requirements decrease because $\mathrm{NH}_{4}^{+}$assimilation does not require Mo. While Mo is the most abundant transition metal in seawater $(107 \mathrm{nM}$; Collier, 1985), Mo concentrations are low in most freshwaters $(<20 \mathrm{nM})$, which raises the question of whether $\mathrm{N}$ assimilation in low-Mo freshwater ecosystems is limited by Mo availability when $\mathrm{NH}_{4}^{+}$concentrations are scarce enough that organisms must rely on $\mathrm{N}_{2}$ and $\mathrm{NO}_{3}^{-}$for their $\mathrm{N}$ sources.

In this paper, we review both laboratory and field experiments in aquatic (and briefly, soil) environments that have tested the effect of varying Mo concentration on $\mathrm{N}$ assimilation via $\mathrm{N}_{2}$ fixation and $\mathrm{NO}_{3}^{-}$reduction. This research dates back to the first half of the twentieth century, when studies with pure cultures showed that removal of Mo from growth media induced symptoms of $\mathrm{N}$-limitation in $\mathrm{N}_{2}$-fixing bacteria (Bortels, 1930, 1940) and $\mathrm{NO}_{3}^{-}$-assimilating fungi (Steinberg, 1937). Since then, it has been shown that $\mathrm{N}_{2}$ fixation requires more Mo than $\mathrm{NO}_{3}^{-}$assimilation, scarce Mo limits $\mathrm{N}$ assimilation in a wide range of natural environments, and Mo bioavailability may decrease with increasing atmospheric $\mathrm{CO}_{2}$, leading to suppressed terrestrial $\mathrm{N}_{2}$ fixation (Hungate et al., 2004). We focus particular attention on previous and current research of Mo limitation of $\mathrm{N}$ assimilation at Castle Lake, CA, the only aquatic habitat in the world that has been the subject of multiple decades of Mo limitation research. We summarize new results on the effect of Mo additions on total protein abundance and activity of enzymes involved in $\mathrm{NO}_{3}^{-}$assimilation in Castle Lake, as well as high-resolution Mo depth profiles that suggest Mo may be limiting $\mathrm{N}_{2}$ fixation by lake periphyton communities. Finally, we discuss future research directions and novel techniques that hold promise for advancing research on this topic.

\section{PURE CULTURE STUDIES}

Research on Mo requirements for $\mathrm{N}$ assimilation in aquatic microbes has largely focused on heterocystous cyanobacteria for $\mathrm{N}_{2}$ fixation studies and green algae for $\mathrm{NO}_{3}^{-}$assimilation studies 
(Table 1). In instances where growth of heterocystous cyanobacteria was compared on different $\mathrm{N}$ sources, Mo requirements were consistently higher in the $\mathrm{N}_{2}$-fixing than $\mathrm{NO}_{3}^{-}$-grown condition (Table 1), as predicted based on specific activity of the nitrogenase vs. nitrate reductase enzymes (see below).

\section{NITROGEN FIXATION}

The first reports that Mo was a bioessential element for $\mathrm{N}_{2}$ fixation were published by the German microbiologist Hermann Bortels on the soil bacterium Azotobacter chroococum (Bortels, 1930) and the aquatic heterocystous cyanobacterium Nostoc/Anabaena (Bortels, 1940). Since Bortels' early studies, Nostoc/Anabaena and Azotobacter strains have been model organisms for the study of Mo requirements for $\mathrm{N}_{2}$ fixation. Subsequent studies showed that Anabaena had optimal growth at dissolved Mo concentrations in the range of 50-2000 nM (Wolfe, 1954; Jacob and Lind, 1977; ter Steeg et al., 1986; Attridge and Rowell, 1997) and that Mo limitation of $\mathrm{N}_{2}$ fixation occurred at 15 nM Mo (Fay and Vasconcelos, 1974; Attridge and Rowell, 1997; Zerkle et al., 2006; Glass et al., 2010). The onset of Mo limitation requires several transfers to ensue, likely due to the expression of high-affinity ModABC $\mathrm{MoO}_{4}^{2-}$ uptake systems, which are widely distributed in bacteria and archaea (Self et al., 2001; Zhang and Gladyshev, 2008) and have been characterized in Nostoc/Anabaena (Thiel et al., 2002; Zahalak et al., 2004).

All of the studies mentioned above were performed on freshwater cyanobacteria (Nostoc/Anabaena). To our knowledge, no previous studies have explored the effect of varying Mo concentration on marine microbes, although one previous study looked at such an effect on coastal heterocystous cyanobacteria (Glass et al., 2010). In recent years there have been a number of reports of intracellular Mo abundances in marine cyanobacteria that enable us to compare approximate Mo requirements between freshwater, coastal, and marine cyanobacteria (Table $\mathbf{1}$ ). When grown at Mo concentrations typical of freshwaters $(<20 \mathrm{nM})$, freshwater heterocystous cyanobacteria have Mo:C ratios of $0.1-3 \mu \mathrm{mol} \mathrm{mol}^{-1}$ (ter Steeg et al., 1986; Glass et al., 2010). When grown at higher Mo concentrations, they can accumulate Mo up to extremely high levels (>100 $\mu \mathrm{mol} \mathrm{mol}^{-1}$; Glass et al., 2010). Cultured coastal heterocystous cyanobacteria have Mo:C ratios of $2-4 \mu \mathrm{mol}$

Table 1 | Previous studies of Mo dependence of $\mathrm{N}_{2}$ fixation and nitrate assimilation in cyanobacteria and algae.

\begin{tabular}{|c|c|c|c|c|c|}
\hline Species name & Organism type & Aquatic habitat & $\begin{array}{l}\text { Mo requirements by } \\
\text { N source }\end{array}$ & $\begin{array}{l}\text { Mo:C } \\
\left(\mu \mathrm{mol} \mathrm{mol}^{-1}\right)\end{array}$ & References \\
\hline Nostoc/Anabaena sp. & Cyanobacterium & Freshwater & $\mathrm{N}_{2}$ & - & Bortels, 1940 \\
\hline Chlorella pyrendoisa & Green alga & Freshwater & $\mathrm{NO}_{3}^{-}$ & - & $\begin{array}{l}\text { Walker, 1953; Loneragan } \\
\text { and Arnon, } 1954\end{array}$ \\
\hline Anabaena cylindrica & Cyanobacterium & Freshwater & $\mathrm{N}_{2}>\mathrm{NO}_{3}^{-}>\mathrm{NH}_{4}^{+}$ & - & $\begin{array}{l}\text { Fogg and Wolfe, 1954; } \\
\text { Wolfe, 1954; Fay and } \\
\text { Vasconcelos, 1974; } \\
\text { Jacob and Lind, 1977; } \\
\text { Attridge and Rowell, } \\
1997\end{array}$ \\
\hline Anabaena oscillarioides & Cyanobacterium & Freshwater & $\mathrm{N}_{2}$ & $0.1-3^{a}$ & ter Steeg et al., 1986 \\
\hline Scenedesmus obliquus & Green alga & Freshwater & $\mathrm{NO}_{3}^{-}>\mathrm{NH}_{4}^{+} \cong$ urea & - & $\begin{array}{l}\text { Arnon et al., 1955; } \\
\text { Ichioka and Arnon, } 1955\end{array}$ \\
\hline Scenedesmus acutus & Green alga & Freshwater & $\mathrm{NO}_{3}^{-}$ & - & Glass, 2011 \\
\hline Navicula pelliculosa & Diatom & Freshwater & $\mathrm{NO}_{3}^{-}$ & - & Wallen and Cartier, 1975 \\
\hline Chlamydomonas reinhardtii & Green alga & Freshwater & $\mathrm{NO}_{3}^{-}$ & - & Wallen and Cartier, 1975 \\
\hline Anacystis nidulans ${ }^{b}$ & Cyanobacterium & Freshwater & $\mathrm{NO}_{3}^{-}>\mathrm{NO}_{2}^{-}>\mathrm{NH}_{4}^{+}$ & - & Peschek, 1979 \\
\hline Anabaena variabilis ATCC 29413 & Cyanobacterium & Freshwater & $\mathrm{N}_{2}$ & - & $\begin{array}{l}\text { Attridge and Rowell, } \\
\text { 1997; Zerkle et al., } 2006\end{array}$ \\
\hline Nostoc sp. PCC 7120 & Cyanobacterium & Freshwater & $\mathrm{N}_{2}>\mathrm{NO}_{3}^{-}$ & $0.2-132$ & Glass et al., 2010 \\
\hline Nostoc sp. CCMP 2511 & Cyanobacterium & Coastal & $\mathrm{N}_{2}>\mathrm{NO}_{3}^{-}$ & $0.5-5.8$ & Glass et al., 2010 \\
\hline Aphanizomenon sp. & Cyanobacterium & Coastal & $\mathrm{N}_{2}$ & $0.8-2.0$ & Walve and Larsson, 2007 \\
\hline Nodularia spumigena & Cyanobacterium & Coastal & $\mathrm{N}_{2}$ & $0.8-2.0$ & Walve and Larsson, 2007 \\
\hline $\begin{array}{l}\text { Trichodesmium erythraeum } \\
\text { strain IMS101 }\end{array}$ & Cyanobacterium & Marine & $\mathrm{N}_{2}$ & $1.0-6.6$ & Tuit et al., 2004 \\
\hline $\begin{array}{l}\text { Trichodesmium (field samples } \\
\text { from North Atlantic) }\end{array}$ & Cyanobacterium & Marine & $\mathrm{N}_{2}$ & $9-54$ & $\begin{array}{l}\text { Tuit et al., 2004; Nuester } \\
\text { et al., } 2012\end{array}$ \\
\hline $\begin{array}{l}\text { Crocosphaera watsonii strain } \\
\text { WH8501 }\end{array}$ & Cyanobacterium & Marine & $\mathrm{N}_{2}$ & $0.6-0.9$ & Tuit et al., 2004 \\
\hline
\end{tabular}

${ }^{a}$ Calculated by assuming that $45 \%$ of dry biomass weight is carbon.

${ }^{b}$ Renamed Synechococcus elongatus PCC 7942. 
$\mathrm{mol}^{-1}$ when grown at seawater Mo concentrations, similar to the natural range observed in the heterocystous cyanobacteria Aphanizomenon sp. and Nodularia spumigena sampled from the Baltic Sea (Walve and Larsson, 2007). Interestingly, marine nonheterocystous cyanobacteria Trichodesmium erythraeum strain IMS101 and Crocosphaera watsonii strain WH8501 have similar Mo quotas to freshwater and coastal cyanobacteria when cultivated in the laboratory $\left(0.6-6.6 \mu \mathrm{mol} \mathrm{mol}{ }^{-1} \mathrm{Mo}: \mathrm{C}\right)$, but Trichodesmium sp. sampled in the North Atlantic have much higher intracellular Mo (9-54 $\mu \mathrm{mol} \mathrm{mol}{ }^{-1} \mathrm{Mo}$ :C; Tuit et al., 2004; Nuester et al., 2012), suggesting that they may have higher Mo requirements than other cyanobacteria and/or that they have a mechanism for Mo storage.

Organisms with alternative nitrogenases (containing vanadium (V) or iron ( $\mathrm{Fe}$ ) in place of $\mathrm{Mo}$ ) express them instead of Mo nitrogenase under Mo limitation (Robson et al., 1986). Such alternative nitrogenases are rare in heterocystous cyanobacteria but are more common in soil bacteria such as Azotobacter (Betancourt et al., 2008), likely because the average $\mathrm{V}$ concentration in soils is $\sim 100$-fold higher than Mo (Gupta, 1997). Alternative nitrogenases are less efficient at $\mathrm{N}_{2}$ fixation than Mo nitrogenases and thus Mo nitrogenases are expressed when sufficient Mo is available (Eady, 1996). Recently, it was discovered that Azotobacter vinelandii produces organic compounds under Mo and V limitation that form strong complexes with $\mathrm{Mo}$ and $\mathrm{V}$ and are available for cellular uptake (Liermann et al., 2005; Bellenger et al., 2008, 2011). Such "molybdophores" are one of several mechanisms that $\mathrm{N}_{2}$ fixers possess for combatting Mo limitation, with other examples including high affinity Mo uptake systems and Mo storage proteins, including MoSto (Pienkos and Brill, 1981; Fenske et al., 2005) and Mop (Hinton and Merritt, 1986; Schüttelkopf et al., 2002; Pau, 2004).

\section{NITRATE ASSIMILATION}

Mo was first reported to be essential for $\mathrm{NO}_{3}^{-}$assimilation in the fungus Aspergillus niger (Steinberg, 1937), which required additional Mo when cultivated on media containing $\mathrm{NO}_{3}^{-}$than $\mathrm{NH}_{4}^{+}$. Follow-up studies showed that this higher Mo demand for growth on $\mathrm{NO}_{3}^{-}$than $\mathrm{NH}_{4}^{+}$was also present in green algae Chlorella pyrendoisa (Walker, 1953) and Scenedesmus obliquus (Arnon et al., 1955; Ichioka and Arnon, 1955) and the cyanobacterium Anacystis nidulans (later renamed Synechococcus elongatus PCC 7942; Peschek, 1979). We found that the green alga Scenedesmus acutus grown in chemostats contained $60 \%$ higher chlorophyll $a$, $3000 \%$ higher nitrate reductase activity and 80\% higher cellular Mo when grown on high concentrations of Mo $(90 \mu \mathrm{M})$ than under Mo limitation (1 nM; Glass, 2011). Studies of the purified assimilatory nitrate reductase verified that the enzyme requires Mo for activity (Nicholas and Nason, 1954; Nicholas et al., 1954; Vega et al., 1971) and contains one molybdopterin cofactor per active site (Solomonson et al., 1986).

Different organisms vary in how much Mo they require for $\mathrm{NO}_{3}^{-}$assimilation. For instance, the freshwater diatom Navicula pelliculosa is more susceptible to Mo limitation of photosynthesis and $\mathrm{NO}_{3}^{-}$uptake than the freshwater green alga Chlamydomonas reinhardtii (Wallen and Cartier, 1975). This may be due to the presence of a high-affinity eukaryotic $\mathrm{MoO}_{4}^{2-}$ uptake system (MOT1) in C. reinhardtii that is absent from diatoms (Tejada-Jimenez et al., 2007). The spotty distribution of MOT1 in eukaryotes was confirmed by a recent bioinformatic survey (Zhang and Gladyshev, 2010). It is possible that eukaryotes containing MOT1 or other unknown high-affinity Mo transporters can cope with Mo limitation for longer time periods than other organisms that lack such transporters.

\section{COMPARISON OF MO REOUIREMENTS}

Models and experiments have demonstrated that $\mathrm{N}_{2}$ fixation requires more Mo than $\mathrm{NO}_{3}^{-}$assimilation, while other more chemically-reduced forms of $\mathrm{N}$, such as $\mathrm{NH}_{4}^{+}$, do not require Mo for assimilation. This is because the specific reaction rate of nitrate reductase ( $\mathrm{mol} \mathrm{N}$ assimilation per $\mathrm{mol} \mathrm{Mo} \mathrm{s}{ }^{-1}$ ) is 2-3 orders of magnitude higher than nitrogenase (Sprent and Raven, 1985). Based on this difference in activity, it has been calculated that a $\mathrm{N}_{2}$-fixing cell requires $\sim 125 \times$ more Mo per cell than a $\mathrm{NO}_{3}^{-}$-grown cell (Sprent and Raven, 1985; Raven, 1988). The greater need for Mo during $\mathrm{N}_{2}$ fixation vs. $\mathrm{NO}_{3}^{-}$assimilation was experimentally demonstrated for both cyanobacteria and legumes containing symbiotic $\mathrm{N}_{2}$ fixers in their root nodules (Anderson and Spencer, 1949, 1950; Fogg and Wolfe, 1954; Wolfe, 1954). In accordance with this higher need, cellular Mo quotas are also higher when cyanobacteria are grown on $\mathrm{N}_{2}$ than $\mathrm{NO}_{3}^{-}$(Glass et al., 2010).

\section{FIELD STUDIES}

Dissolved Mo concentrations have been measured in a large number of globally distributed freshwater lakes, and range from $<0.1-13 \mathrm{nM}$ (Table 2). Mo concentrations increase with salinity, and therefore saline lakes often contain much higher concentrations of Mo than freshwater lakes (Marino et al., 1990; Johannesson et al., 2000). In this section we review previous studies on Mo limitation in freshwater lakes, with particular emphasis on Castle Lake in northern California, USA. We summarize new data for Castle Lake, including results of experiments exploring the influence of $\mathrm{Mo}$ and $\mathrm{NO}_{3}^{-}$additions on the activity of enzymes involved in $\mathrm{NO}_{3}^{-}$assimilation, and dissolved Mo depth profiles. In later sections we discuss the possibility of Mo limitation of $\mathrm{N}$ assimilation in marine and soil environments. Mo has been clearly shown to limit $\mathrm{N}_{2}$ fixation in temperate and tropical soil ecosystems, whereas the evidence is more ambiguous for marine environments.

\section{MO LIMITATION IN CASTLE LAKE AND OTHER FRESHWATERS Previous studies}

Early studies tested the response of Mo additions to oligotrophic lakes in Alaska, California, and New Zealand (Goldman, 1964). Mo additions to bottle incubations were performed for 3 lakes in Alaska, 13 lakes in the Klamath Mountains of California, 2 lakes in the Sierra Nevada Mountains of California and 2 lakes in New Zealand (Figure 1). Mo concentrations in Lake Aleknagik (Alaska) and Lakes Coleridge and Lyndon (New Zealand) were $<0.7 \mathrm{nM}$ (Goldman, 1964) and lakes in the Sierra Nevada averaged $4 \mathrm{nM}$ (Bradford et al., 1968). Response to Mo additions was measured by comparing photosynthetic $\mathrm{H}^{14} \mathrm{CO}_{3}^{-}$uptake between control bottles and bottles amended with $40 \mathrm{nM}$ Mo. The majority of lakes showed a significant increase in ${ }^{14} \mathrm{C}$ uptake after Mo addition: $0.1-10 \%$ increase over controls (7 lakes), 
Table 2 | Dissolved Mo concentrations for Castle Lake and other freshwater lakes around the world.

\begin{tabular}{|c|c|c|}
\hline $\begin{array}{l}\text { Lake name and location } \\
\text { (number of lakes in study) }\end{array}$ & $\begin{array}{l}\text { Dissolved Mo } \\
\text { (nM) }\end{array}$ & References \\
\hline Castle Lake, California, USA & $2-4$ & $\begin{array}{l}\text { Bachmann and } \\
\text { Goldman, 1964; Glass, } \\
2011\end{array}$ \\
\hline Clear Lake, Colorado, USA & $1-4$ & $\begin{array}{l}\text { Elser and Glass, } \\
\text { unpublished data }\end{array}$ \\
\hline Esthwaite Water, England & $0.1-2.6$ & Achterberg et al., 1997 \\
\hline $\begin{array}{l}\text { Linsley Pond, Connecticut, } \\
\text { USA }\end{array}$ & $0.4-2.7$ & Cowgill, 1977 \\
\hline New Zealand lakes (3) & $<0.7$ & Goldman, 1964 \\
\hline Alaska lakes (3) & $\leq 0.6$ & Goldman, 1964 \\
\hline $\begin{array}{l}\text { Mirror Lake, New } \\
\text { Hampshire, USA }\end{array}$ & $0.1-0.3$ & Cole et al., 1986 \\
\hline Japan lakes (13) & $0.5-13$ & Sugawara et al., 1961 \\
\hline Lake Greifen, Switzerland & $3-5$ & Magyar et al., 1993 \\
\hline Lake Insjön, Sweden & 6.4 & Lithner et al., 2000 \\
\hline Lake Lundsjön, Sweden & 0.8 & Lithner et al., 2000 \\
\hline Eastern Canadian lakes (4) & $0.1-3.4$ & Chappaz et al., 2008 \\
\hline Hall Lake, Washington, USA & $1-2$ & Balistrieri et al., 1994 \\
\hline $\begin{array}{l}\text { Sierra Nevada lakes (170), } \\
\text { California, USA }\end{array}$ & $0.03-10$ & Bradford et al., 1968 \\
\hline Northern Germany lakes (8) & $0.5-10$ & Groth, 1971 \\
\hline Amazonas, Brazil lakes (3) & $4-8$ & Groth, 1971 \\
\hline
\end{tabular}

10.1-20\% increase over controls (9 lakes), 20.1-30\% increase over controls (1 lake) and 40.1-50\% increase over controls (1 lake; Figure 1). Only 2 lakes of the 20 tested did not respond to Mo additions.

The lake with the most positive response to Mo addition of the 20 tested was Castle Lake, a small $\left(0.2 \mathrm{~km}^{2}\right)$ meso-oligotrophic, subalpine lake in the Klamath Mountains of northern California with low dissolved Mo (2-4 nM). These low Mo concentrations are likely a result of the ultramafic deposits underlying the lake's watershed, which contain very low concentrations of Mo (Kuroda and Sandell, 1954; Glass, 2011; Glass, J. B., Chappaz, A., Eustis, B., Heyvaert, A. C., Waetjen, D., Hartnett, H. E., and Anbar, A. D., Molybdenum geochemistry in Castle Lake, California, in review, Geochim. Cosmochim. Acta). Addition of $1 \mu \mathrm{M}$ Mo increased the rate of photosynthesis in lake surface phytoplankton communities in the summer, fall, and winter months (Goldman, 1960). Lower concentrations of Mo stimulated primary productivity in January than in June or October, suggesting that planktonic communities were more Mo-limited during the winter than the summer. This explanation is reasonable given that Castle Lake water sampled from under the ice had lower dissolved Mo concentrations (0.1-0.9 nM; Glass, 2011; Glass et al., in review) than surface lake water sampled in the mid-summer 2008 and 2009 (2.4-2.9 nM; Figure 3A; see below). Similarly, pronounced winter depletions of Mo have been measured in Lake Donk, Belgium (Dumont, 1972) and Linsley Pond, Connecticut (Cowgill, 1977). For more on the geochemical cycling of Mo in Castle Lake, see Glass et al., (in review).
Two experimental whole-lake additions of Mo were performed in Castle Lake in the 1960s. In July 1963 and again in June $1969,6.3 \mathrm{~kg}$ of Mo was added as solid-phase sodium molybdate $\left(\mathrm{Na}_{2} \mathrm{MoO}_{4}\right)$ to the lake's epilimnion to stimulate primary productivity (Goldman, 1966, 1972). These Mo additions increased dissolved Mo in the epilimnion from $\sim 2-5 \mathrm{nM}$ to $50-80 \mathrm{nM}$. Following the 1963 experimental addition of Mo to the lake, primary productivity in the epilimnion increased $40 \%$ over the previous year (Goldman, 1966). The golden alga Dinobryon sertularia exhibited the largest increase in cell numbers (Goldman, 1972; Jassby and Goldman, 1974). Trout, cladoceran, and copepod yields also increased.

Subsequent studies showed that Mo limitation of primary productivity in Castle Lake was likely a result of insufficient Mo for maximal rates of $\mathrm{NO}_{3}^{-}$assimilation. Additions of $50 \mathrm{nM}$ Mo to bottle incubations of Castle Lake water led to increased $\mathrm{NO}_{3}^{-}$uptake (up to $60 \%$ ), but only when $\mathrm{NO}_{3}^{-}-\mathrm{N}$ concentrations were $>1 \mu \mathrm{M}$ and $\mathrm{NH}_{4}^{+}-\mathrm{N}$ was $<0.1 \mu \mathrm{M}$ (Axler et al., 1980). Regeneration of $\mathrm{NH}_{4}^{+}$by zooplankton excretion and microbial mineralization are important $\mathrm{N}$ sources for the Castle Lake phytoplankton community (Axler et al., 1981; Zehr et al., 1985). In the epilimnion, $\mathrm{NH}_{4}^{+}$assimilation rates were significantly higher than those of $\mathrm{NO}_{3}^{-}$throughout the summer (Axler et al., 1981, 1982) and mid to late-summer regeneration of $\mathrm{NH}_{4}^{+}$contributed more than $50 \%$ of the total $\mathrm{N}$ assimilated (Axler et al., 1981). Small amounts of $\mathrm{NH}_{4}^{+}-\mathrm{N}(0.3-0.4 \mu \mathrm{M})$ were shown to inhibit $\mathrm{NO}_{3}^{-}$assimilation by more than $75 \%$ in the Castle Lake epilimnion (Priscu et al., 1985), whereas higher $\mathrm{NH}_{4}^{+}$concentrations were required for inhibition at greater depths. At $20 \mathrm{~m}, \sim 3 \mu \mathrm{M}$ $\mathrm{NH}_{4}^{+}-\mathrm{N}$ was required to significantly inhibit $\mathrm{NO}_{3}^{-}$assimilation, whereas at $25 \mathrm{~m}$, enrichment with $5.4 \mu \mathrm{M} \mathrm{NH}_{4}^{+}-\mathrm{N}$ resulted in minimal inhibition (Priscu et al., 1985). From 1976-2010, mean $\mathrm{NH}_{4}^{+}$-N during the ice-free growing season (June through midSeptember) was $0.3 \pm 0.2$ (mean \pm 1 s.d.) $\mu \mathrm{M}$ in the epilimnion at $3 \mathrm{~m}, 0.3 \pm 0.2 \mu \mathrm{M}$ in the upper hypolimnion at $15 \mathrm{~m}$ and $1.0 \pm 0.9 \mu \mathrm{M}$ in the mid-hypolimnion at $25 \mathrm{~m}$ (CLEREP, 2011). Therefore, the epilimnetic phytoplankton community is probably more susceptible to $\mathrm{NH}_{4}^{+}$suppression of $\mathrm{NO}_{3}^{-}$assimilation than the hypolimnetic community, where mean $\mathrm{NH}_{4}^{+}$levels are typically below the inhibition threshold (Axler et al., 1980; Axler and Goldman, 1981; Priscu et al., 1985). Thus, it is reasonable to expect that Mo requirements increase with depth in Castle Lake if $\mathrm{NO}_{3}^{-}$is a more important $\mathrm{N}$ source in the hypolimnion than in the epilimnion.

\section{CURRENT STUDY: ENZYME BIOASSAYS}

Building on previous isotopic tracer $\left({ }^{15} \mathrm{~N},{ }^{13} \mathrm{~N}\right.$, and $\left.{ }^{14} \mathrm{C}\right)$ uptake experiments in Castle Lake (Goldman, 1960; Axler et al., 1980, 1982; Axler and Goldman, 1981; Axler and Reuter, 1996), we investigated the effect of Mo availability on the enzyme activity of key $\mathrm{N}$ assimilation proteins and total protein abundances at three depths in Castle Lake. In July 2008, we assayed the activity of the first and third enzymes involved in $\mathrm{NO}_{3}^{-}$assimilation (the Mo-containing eukaryotic nitrate reductase and the nonmetal-containing enzyme glutamine synthetase) and total protein content after the addition of $100 \mu \mathrm{M} \mathrm{NO}_{3}^{-}$as $\mathrm{NaNO}_{3}$ and $100 \mathrm{nM}$ $\mathrm{Mo}$ as $\mathrm{Na}_{2} \mathrm{MoO}_{4}$ to bottle experiments (background $\mathrm{NO}_{3}^{-}-\mathrm{N}$ 


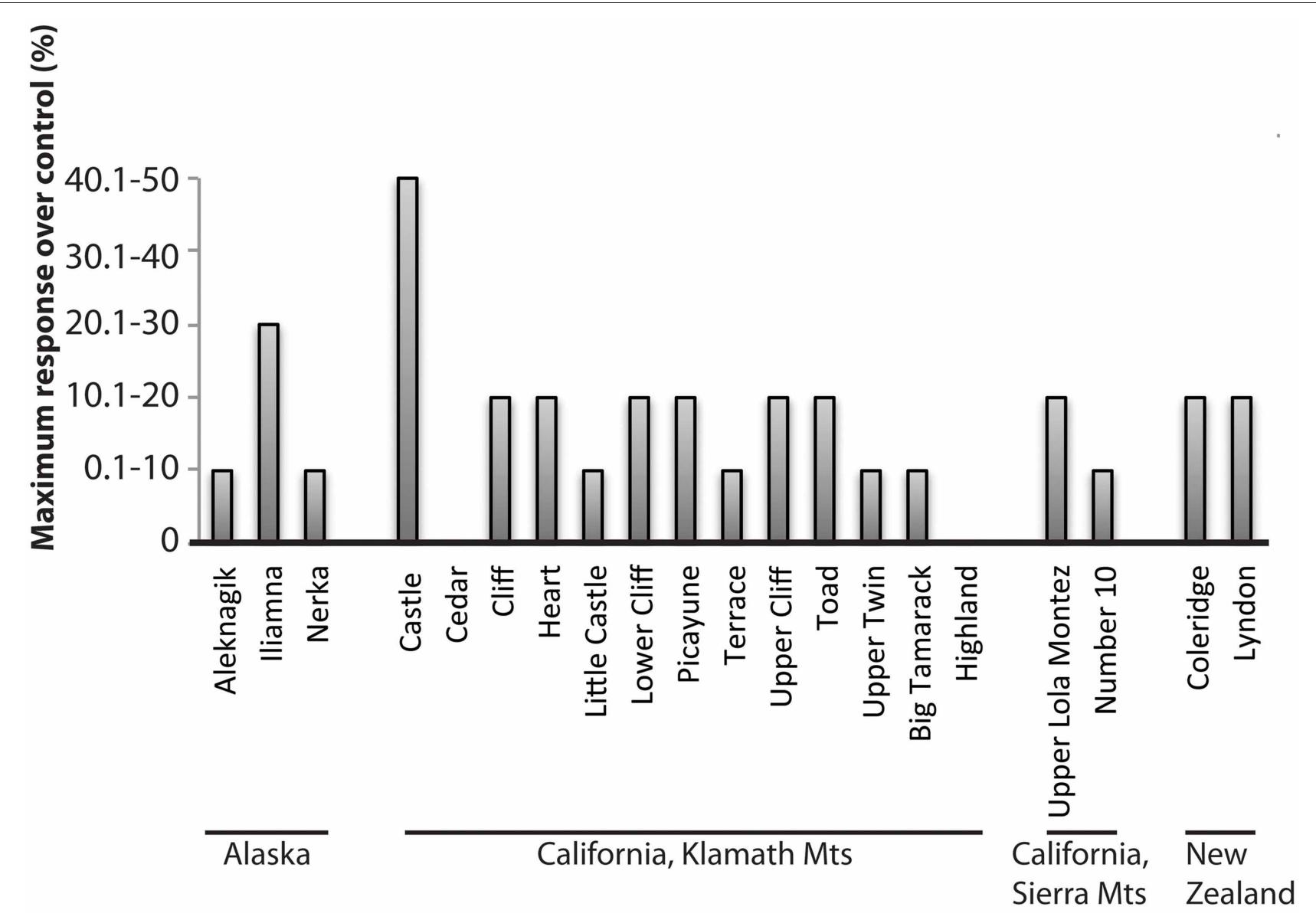

FIGURE 1 | Maximum response of bottle incubations after addition of $40 \mathrm{nM}$ Mo in 20 lakes, in units of percent increase over control. Compiled from Goldman (1964).

concentrations at the start of the experiment were $0.1 \mu \mathrm{M}$ at $3 \mathrm{~m}, 0.2 \mu \mathrm{M}$ at $15 \mathrm{~m}$, and $1.6 \mu \mathrm{M}$ at $25 \mathrm{~m}$; background $\mathrm{Mo}$ was 2-4 nM; see Glass, 2011 for experimental details). These experiments showed a consistent positive response at the lower two depths (15 and $25 \mathrm{~m}$ ), but only in the $+\mathrm{N}+$ Mo treatments (Figure 2). This hypolimnetic response occurred for all three measurements: nitrate reductase activity (Figure 2A), glutamine synthetase activity (Figure 2B), and soluble protein content (Figure 2C), suggesting that supplemental Mo enabled added $\mathrm{NO}_{3}^{-}$to be assimilated into protein. Ambient $\mathrm{NH}_{4}^{+}-\mathrm{N}$ concentrations were $0.2 \mu \mathrm{M}$ at $3 \mathrm{~m}$ and $\leq 0.02 \mu \mathrm{M}$ at 15 and $25 \mathrm{~m}$. The lack of response to $+\mathrm{N}+\mathrm{Mo}$ treatments at $3 \mathrm{~m}$ suggests that $0.2 \mu \mathrm{M} \mathrm{NH}_{4}^{+}-\mathrm{N}$, slightly lower than the inhibition threshold of 0.3-0.4 $\mu \mathrm{M} \mathrm{NH}_{4}^{+}-\mathrm{N}$ reported by Priscu et al. (1985), was inhibiting $\mathrm{NO}_{3}^{-}$uptake. The strong response to $+\mathrm{N}+$ Mo additions at 15 and $25 \mathrm{~m}$ suggests that hypolimnetic microbial communities were $\mathrm{Mo}-\mathrm{NO}_{3}^{-}$co-limited; that is, addition of only one nutrient did not stimulate enzyme activity and protein synthesis because the other nutrient was limiting-only the simultaneous addition of both nutrients produced a positive response. This finding is in accordance with scarce $\mathrm{NH}_{4}^{+}\left(\leq 0.02 \mu \mathrm{M} \mathrm{NH}_{4}^{+}-\mathrm{N}\right)$ in the hypolimnion, reducing the possibility of $\mathrm{NH}_{4}^{+}$inhibition.

\section{CURRENT STUDY: MO DEPTH PROFILES}

We extended previous studies of Castle Lake Mo bioavailability (Bachmann and Goldman, 1964; Goldman, 1966) by obtaining high-resolution dissolved Mo depth profiles from the center of Castle Lake on 16 July 2008 and 27 June 2009 (see Glass, 2011 for details). The dissolved Mo content of the Castle Lake water column ranged from 2 to $4 \mathrm{nM}$ (Figure 3), similar to values reported from the 1960s using different analytical methods. Surface water Mo concentrations were 2.9 and $2.4 \mathrm{nM}$ in 2008 and 2009, respectively. Both years, Mo concentration minima occurred near the thermocline, where Mo was lower by $0.5-0.8 \mathrm{nM}$ than in shallower and deeper waters. The concentration minimum was offset $\sim 5 \mathrm{~m}$ deeper in 2008 than 2009. The Mo minimum was located at a shallower depth $(5-10 \mathrm{~m})$ than the deep chlorophyll $a$ maximum (15-20 m), whereas Mo minima and dissolved $\mathrm{O}_{2}$ maxima occurred at similar depths (Figures 3A,B). Dissolved Mo was relatively constant down to about $20 \mathrm{~m}$, and then increased toward the lake bottom, suggesting that sediments are a source of Mo to the lake in the mid-summer (Glass et al., in review; Figure 3A).

The finding of Mo minima in the Castle Lake epilimnion suggests that dissolved Mo is being taken up biologically in excess of that supplied by watershed and sediment inputs. The concurrence 


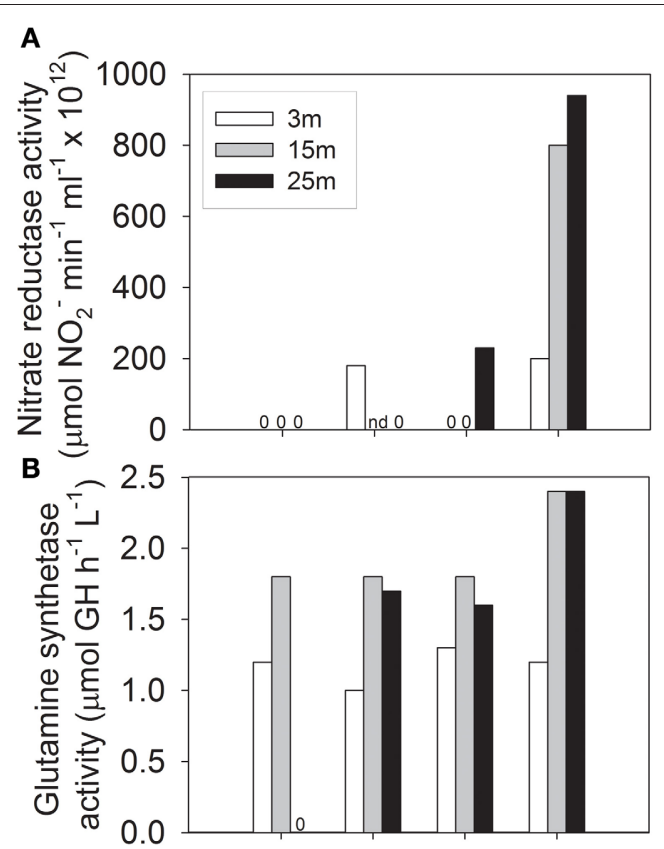

C

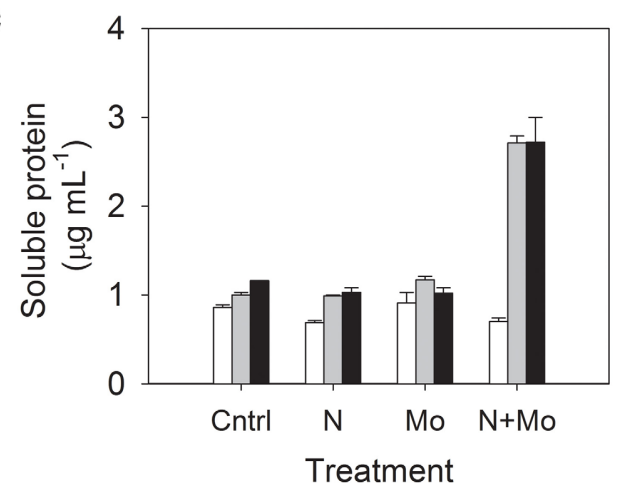

FIGURE 2 | Results of bioassay experiments at three depths in Castle Lake in July 2008 for control (Cntrl), +nitrate (N), +molybdenum (Mo), and +nitrate +molybdenum ( $\mathrm{N}+\mathrm{Mo}$ ) treatments: (A) nitrate reductase activity; (B) glutamine synthetase activity; (C) soluble protein content (" 0 " stands for undetectable activity and "nd" stands for "no data" "GH" stands for $\gamma$-glutamyl hydroxamate). After Glass (2011).

of dissolved Mo minima and dissolved $\mathrm{O}_{2}$ maxima near the thermocline may provide clues as to which Castle Lake microbial community is responsible for the prominent Mo drawdown between 5 and $10 \mathrm{~m}$ depth. Positive heterograde $\mathrm{O}_{2}$ profiles like those of Castle Lake, exhibiting an $\mathrm{O}_{2}$ maximum at the thermocline, can arise from high phytoplankton photosynthesis and/or diffusion of $\mathrm{O}_{2}$ (produced by submerged macrophytes, periphyton, or phytoplankton) from the littoral zone into the thermocline (Wetzel, 2001). The littoral zone of Castle Lake is an extensive shallow (3-5 $\mathrm{m}$ ) platform with a well-studied benthic periphyton community that includes an expansive epipelic (i.e., living freely on sediment surfaces) plain comprised of a mixed community of diatoms, chlorophytes, and non-heterocystous cyanobacteria, and a fringing epilithic (i.e., growing on a rock surface) community dominated by $\mathrm{N}_{2}$-fixing heterocystous cyanobacteria (Sanders,
1976; Loeb and Reuter, 1981; Reuter et al., 1985; Reuter and Axler, 1988, 1992; Axler and Reuter, 1996), that have high Mo requirements (see above). Even when epilimnetic water is severely depleted in $\mathrm{NO}_{3}^{-}$, the overlying epipelic periphyton can still obtain a significant amount of their $\mathrm{N}$-nutrition by fixing $\mathrm{N}_{2}$ in the dark when they are not producing $\mathrm{O}_{2}$ (Bergman et al., 1997; Berman-Frank et al., 2003) or by assimilating interstitial porewater $\mathrm{NO}_{3}^{-}$that diffuses upward from the sediments (Reuter et al., 1985; Reuter and Axler, 1992). Therefore, this microbial community represents a potentially important sink for available Mo. Neither heterocystous cyanobacteria, nor $\mathrm{N}_{2}$-fixation, have been found in the planktonic communities of the lake over the many years of intensive monitoring (Reuter et al., 1985; Goldman, unpublished). This fact, together with the extremely low rates of planktonic $\mathrm{NO}_{3}^{-}$assimilation rates previously measured in the epilimnion (Gersberg et al., 1978; Axler and Goldman, 1981; Axler et al., 1982), suggests that the Mo minimum at the thermocline likely represents demand by littoral periphyton communities that fix $\mathrm{N}_{2}$ and also assimilate $\mathrm{NO}_{3}^{-}$. This raises the question of whether these periphyton communities are limited for Mo. One previous experiment provides support for this hypothesis: $\mathrm{N}_{2}$ fixation increased $210 \%$ when $50 \mathrm{nM}$ Mo was added to a lake containing $<10 \mathrm{nM}$ Mo in the Great Salt Basin during a cyanobacterium (Aphanizomenon flos-aquae) bloom (Wurtsbaugh, 1988). However, Mo requirements for periphyton microbial communities remain to be determined.

\section{MARINE AND SALINE ENVIRONMENTS}

A long-standing question in oceanography is the cause for widespread $\mathrm{N}$ limitation in marine environments (Vitousek and Howarth, 1991). Mo was long dismissed as a potential limiter of marine $\mathrm{N}$ assimilation due to its high seawater concentration and conservative behavior with depth $(\sim 107 \mathrm{nM}$; Collier, 1985). Robert Howarth and colleagues challenged that assumption by suggesting that high levels of seawater sulfate may compete with Mo uptake (Howarth and Cole, 1985; Howarth et al., 1988). Sulfate $\left(\mathrm{SO}_{4}^{2-}\right)$ and molybdate $\left(\mathrm{MoO}_{4}^{2-}\right.$, the dominant species of Mo in oxic waters) have very similar size and stereochemistry, but sulfate $\left(\mathrm{SO}_{4}^{2-} ; 28 \mathrm{mM}\right)$ is $\sim 10^{5}$-fold more abundant than molybdate $\left(\mathrm{MoO}_{4}^{2} ; 100 \mathrm{nM}\right)$ in seawater. Amendment experiments in the Baltic Sea (with ambient Mo of $20 \mathrm{nM}$ and sulfate of $4.8 \mathrm{mM}$, a S:Mo ratio of 240,000) showed that additions of $100 \mathrm{nM}$ Mo (S:Mo ratio of 40,000) led to $50 \%$ higher $\mathrm{N}_{2}$ fixation rates than the control, whereas additions of $5 \mathrm{mM}$ sulfate ( $\mathrm{S}: \mathrm{Mo}$ ratio of 490,000; roughly 2-fold higher than seawater) led to $\mathrm{N}_{2}$ fixation rates $25 \%$ lower than the control (Howarth and Cole, 1985). However, $\mathrm{N}_{2}$ fixation rates were low in this experiment and the authors warned against extrapolation to marine systems. In follow-up studies with pure cultures and freshwater systems, Mo uptake was inhibited at S:Mo ratios 50-100-fold lower than those present in seawater (Cole et al., 1986, 1993) and addition of sulfate to seawater levels greatly reduced $\mathrm{N}_{2}$ fixation rates (Marino et al., 2003). Also consistent with this hypothesis, the S:Mo ratio in 13 saline lakes in Alberta, Canada was negatively correlated with the abundance of $\mathrm{N}_{2}$-fixing cyanobacteria (Marino et al., 1990).

While these studies lent support to the S/Mo inhibition hypothesis, others challenged it. In situ bioassays performed off 


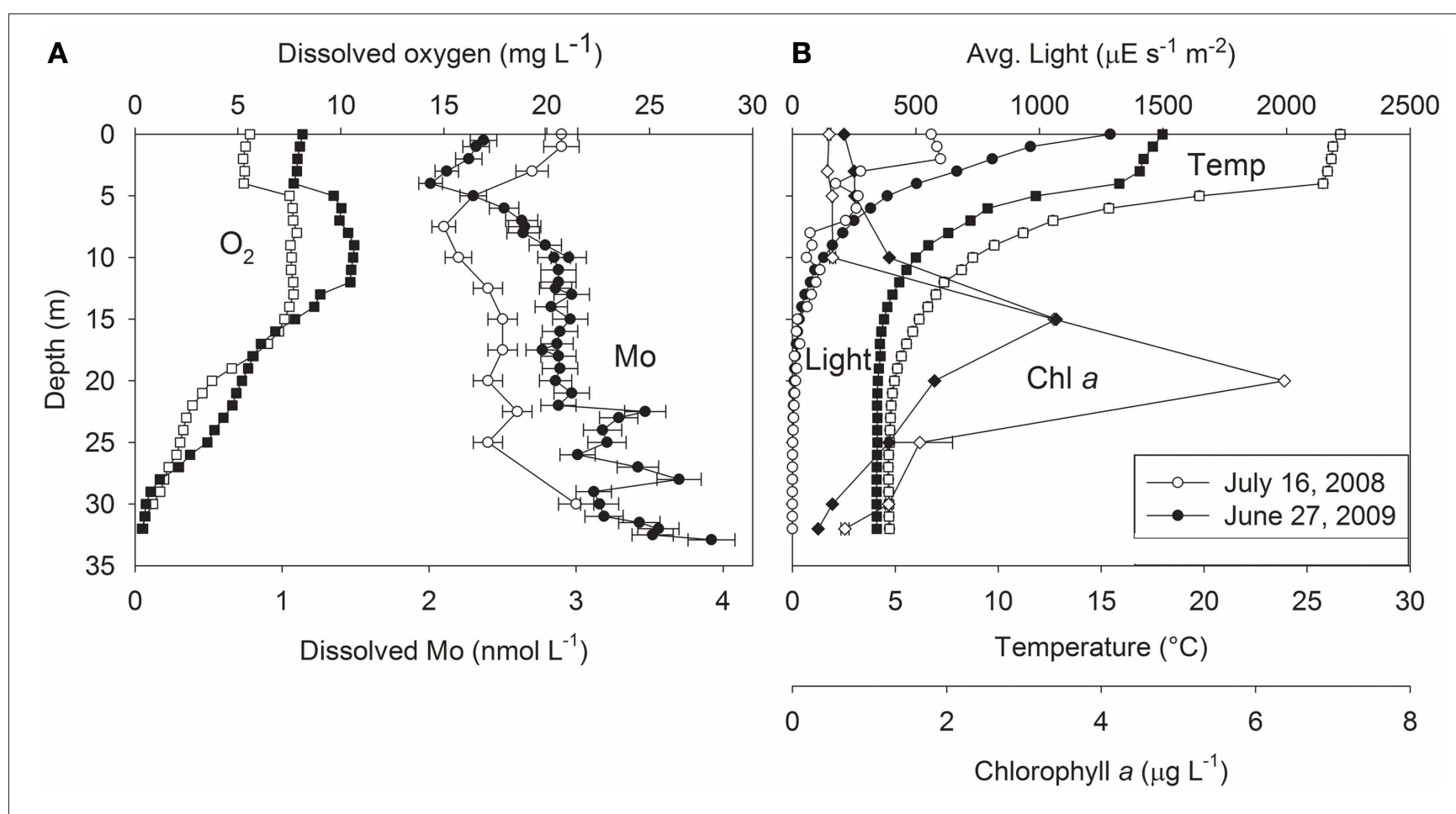

FIGURE 3 | (A) Dissolved oxygen $\left(\mathrm{O}_{2}\right.$; squares) and dissolved molybdenum (Mo; circles), and (B) average light (circles), temperature (squares), and chlorophyll a concentrations ( $\mathrm{Chl}$ a; diamonds) with depth in Castle Lake, from water column samples collected on 16 July 2008 (white symbols) and 27 June 2009 (black symbols). After Glass (2011).

the North Carolina coast showed that addition of $0.1-5 \mu \mathrm{M}$ Mo resulted in no significant change in $\mathrm{N}_{2}$ fixation rates (Paerl et al., 1987; Paulsen et al., 1991). Similarly, mesocosm studies with water sampled from Narragansett Bay, Rhode Island produced no significant change in heterocyst abundance (a proxy for $\mathrm{N}_{2}$-fixing cell abundance) when Mo was increased from ambient levels $(98 \mathrm{nM})$ to $1.23 \mu \mathrm{M}$ under highly $\mathrm{N}$-limited conditions (Marino et al., 2003). Additions of Mo to the Great Salt Lake, which lowered S:Mo ratios from 299,00:1 to 83,000:1, did not significantly stimulate $\mathrm{N}_{2}$ fixation (Wurtsbaugh, 1988). Similarly, Mo additions to 8 of the 13 saline lakes studied by Marino et al. (1990) had no significant effect on phytoplankton biomass (Evans and Prepas, 1997). Finally, Mo uptake by Azotobacter vinelandii was not inhibited at S:Mo ratios up to eight times that of seawater (Paulsen et al., 1991). Overall, it is still unclear whether high $\mathrm{SO}_{4}^{2-}$ inhibits Mo uptake in marine environments, as this question has never been tested in open ocean conditions. However, it seems that marine microbes are adapted to discriminate between $\mathrm{SO}_{4}^{2-}$ and $\mathrm{MoO}_{4}^{2-}$ in a manner that freshwater microbes are not.

\section{SOIL HABITATS}

Since this paper is focused on Mo limitation of aquatic environments, we will touch only briefly on Mo limitation of soil ecosystems. For a much more thorough review of Mo as it relates to soils, crops, and livestock, see Gupta (1997). Studies on Mo deficiencies in soils date back to the 1930s, when Arnon and Stout (1939) first showed that Mo was an essential micronutrient for higher plants. Nitrate was found to accumulate in plant leaf tissues when Mo was omitted from the nutrient medium, presumably because it could not be assimilated into organic matter (Hewitt and Jones, 1947). Mo limitation is especially prevalent on serpentine soils which contain less Mo than other soil types (Walker, 1948). The importance of Mo for symbiotic $\mathrm{N}_{2}$ fixation in alders containing $\mathrm{N}_{2}$-fixing bacteria in their root nodules was first shown by Becking (1961a,b). Goldman (1960, 1972) proposed that alders growing along the shore of Castle Lake may scrub soluble Mo from soil porewaters, thereby competing with the aquatic ecosystem for scarce Mo. More recently, $\mathrm{N}_{2}$ fixation has been found to be limited by Mo availability in both temperate and tropical soils (Silvester, 1989; Barron et al., 2009; Wurzburger et al., 2012). This effect may be exacerbated by rising atmospheric $\mathrm{CO}_{2}$ : Hungate et al. (2004) found that rising atmospheric $\mathrm{CO}_{2}$ led to increased legume $\mathrm{N}_{2}$ fixation during the first year of treatment of an oak woodland, but this response declined and disappeared by the third year and $\mathrm{N}_{2}$ fixation was depressed in the fifth, sixth, and seventh years. This effect was best explained by declines in foliar Mo concentrations with increased atmospheric $\mathrm{CO}_{2}$, suggesting that the bioavailability of Mo in soils declined, likely either by decreased $\mathrm{pH}$ or accumulation of organic matter leading to increased sorption of Mo onto particles. Therefore, Mo limitation of $\mathrm{N}$ assimilation may limit the ability of both terrestrial environments (and possibly aquatic ones as well) to serve as sinks for anthropogenic $\mathrm{CO}_{2}$ emissions.

\section{CONCLUSIONS AND FUTURE DIRECTIONS}

Research on Mo requirements for microbial $\mathrm{N}$ assimilation dates back to the 1930s and has recently been rejuvenated by the important finding that $\mathrm{N}_{2}$ fixation may be limited by decreased Mo 
bioavailability under increased atmospheric $\mathrm{CO}_{2}$ (see above). Studies of pure cultures of cyanobacteria, algae, and soil bacteria have shown that Mo requirements are highest when organisms are fixing $\mathrm{N}_{2}$, lower but still significant when grown on $\mathrm{NO}_{3}^{-}$, and negligible when grown on $\mathrm{NH}_{4}^{+}$. Furthermore, there are differences in Mo requirements among species for a given $\mathrm{N}$ source, likely due to the presence or absence of high-affinity Mo uptake systems and/or other Mo scavenging mechanisms. In situ experiments with natural populations of microbes in lakes have shown that Mo limitation of primary productivity may be widespread, particularly in freshwaters underlain by geologic deposits containing scarce Mo, such as Castle Lake in northern California. Data presented here support the theory, originally put forth in previous studies (Goldman, 1960; Axler et al., 1980; Axler and Goldman, 1981), that Mo availability can limit $\mathrm{NO}_{3}^{-}$assimilation in Castle Lake when $\mathrm{NH}_{4}^{+}$is scarce, and show that this limitation manifests itself in suppressed enzyme activity and protein content. Furthermore, we found circumstantial evidence in Castle Lake Mo and $\mathrm{O}_{2}$ depth profiles that $\mathrm{N}_{2}$ fixation by periphyton communities leads to appreciable dissolved Mo drawdown and thus may also be Mo-limited, an idea that requires future testing. Below we discuss up-and-coming research topics related to Mo-N co-limitation: the bioavailability of different redox states of Mo, the use of Mo isotope systematics to elucidate microbial Mo uptake mechanisms, the possibility of Mo limitation of $\mathrm{N}_{2}$ fixation in the marine environment, and the co-evolution of microbial metabolisms with changing availability of Mo in the ocean through time.

\section{BIOAVAILABILITY OF MO IN DIFFERENT OXIDATION STATES}

While the major Mo species in oxic waters is $\mathrm{Mo}(\mathrm{VI}) \mathrm{O}_{4}^{2-}, \mathrm{Mo}(\mathrm{V})$ was found to comprise up to $15 \%$ of total Mo concentrations in estuarine waters and likely a significant portion of total Mo in many aquatic systems (Wang et al., 2009). It has been proposed that reduced $\mathrm{Mo}(\mathrm{V})$ is more bioavailable than oxidized $\mathrm{Mo}(\mathrm{VI})$ as $\mathrm{MoO}_{4}^{2-}$ because $\mathrm{Mo}^{5+}$ is the redox state of Mo in some enzymes (see references in Wang et al., 2009) and does not compete with $\mathrm{SO}_{4}^{2-}$ during uptake (Howarth and Cole, 1985; Howarth et al., 1988). Recent experiments support this hypothesis: in California lakes of varying trophic status (Lake Tahoe, Walker Lake, and Clear Lake), $\mathrm{N}_{2}$ fixation rates and chlorophyll concentrations were positively correlated with $\mathrm{Mo}(\mathrm{V})$ concentrations, which increased with trophic status from Lake Tahoe to Lake Walker to Clear Lake (Romero et al., 2011). Under reducing conditions often present in sediments and bottom waters, a higher proportion of Mo will be reduced (Wang et al., 2011) or converted to particle-reactive thiomolybdate $\left(\mathrm{Mo}(\mathrm{VI}) \mathrm{O}_{x} \mathrm{~S}_{4-x}^{2-}\right)$ if $\mathrm{H}_{2} \mathrm{~S}$ is present in relatively high concentrations (Helz et al., 1996, 2011; Erickson and Helz, 2000; Vorlicek and Helz, 2002; Vorlicek et al., 2004). Very little is known about the bioavailability of thiomolybdate (and other chemical species of Mo besides $\left.\mathrm{Mo}(\mathrm{VI}) \mathrm{O}_{4}^{2-}\right)$; this is a topic that deserves more attention.

\section{MO ISOTOPIC FRACTIONATION}

Recently, studies revealed that Nostoc/Anabaena and Azotobacter fractionate Mo isotopes with distinct fractionation factors when fixing $\mathrm{N}_{2}$ (Wasylenki et al., 2007; Zerkle et al., 2011). This fractionation likely occurs during uptake by the ModABC system (see above). Although this research is still in its early phases, future studies may benefit from using Mo isotopes to discern the intricacies of Mo biological pools in microbial species.

\section{MO LIMITATION IN THE MARINE ENVIRONMENT?}

Considering the importance of $\mathrm{N}_{2}$ fixation in the marine environment (Sohm et al., 2011 and references therein), surprisingly few studies have investigated Mo requirements for $\mathrm{N}_{2}$-fixing marine microbes compared to the greater number of studies on freshwater microbes. The reason for this gap is likely due to the assumption that dissolved Mo is too abundant in seawater to be a limiting micronutrient (see above). However, non-conservative behavior of Mo in coastal regions has been observed; dissolved Mo drops as low as $30 \mathrm{nM}$ in the Wadden Sea (Dellwig et al., 2007). Although this concentration is still higher than has been shown for Mo requirements in freshwater and (one strain of) coastal cyanobacteria, it is possible that other coastal and open ocean strains require higher Mo, a hypothesis that requires future testing. Furthermore, it is quite possible that $\mathrm{N}_{2}$ fixation in marine sediments (e.g., Dekas et al., 2009) is Mo-limited, as dissolved Mo in marine sediment porewaters may be reduced or converted to particle-reactive thiomolybdate (see above), leaving low levels of bioavailable Mo for microbial $\mathrm{N}_{2}$ fixation. Alternatively, microbes may have evolved yetunknown mechanisms to access Mo in sulfidic sediment porewaters. Finally, the S/Mo inhibition hypothesis still needs to be tested in open ocean conditions. If no inhibition is identified, a thorough study of the differences in $\mathrm{MoO}_{4}^{2-} / \mathrm{SO}_{4}^{2-}$ uptake pathways is needed, as that would imply that marine microbial uptake systems have more specificity for Mo than those of freshwater microbes.

\section{ANCIENT OCEAN MO CHEMISTRY AND EVOLUTION}

While Mo is the most abundant transition metal in the modern ocean, it was likely much scarcer in seawater earlier in earth history and may have been an important limiting micronutrient of marine primary productivity. Before the Great Oxidation Event (GOE) 2.4 billion years ago, the riverine flux of Mo to the ocean would have been small due to minimal oxidative weathering of sulfides, the major source of Mo on the continents (Scott et al., 2008). Nevertheless, Mo proteins seem to have very ancient roots and likely evolved in a low-Mo ocean (Raymond et al., 2004; Boyd et al., 2011; Schoepp-Cothenet et al., 2012). After the GOE up until $\sim 800$ million years ago, the presence of sulfide in the deep ocean (even if present over a relatively small areal extent) may have kept Mo concentrations low enough to limit $\mathrm{N}_{2}$ fixation and perhaps stall the evolution of eukaryotic life (Anbar and Knoll, 2002; Glass et al., 2009; Reinhard, C. T., Planavsky, N. J., Robbins, J., Partin, C., Gill, B. C., Lalonde, S. V., Bekker, A., Konhauser, K. O., and Lyons, T. W. Proterozoic ocean redox and evolutionary stasis, in review, Proc. Natl. Acad. Sci.). Marine Mo concentrations likely rose to near their present values $\sim 600$ million years ago when the ocean became fully oxic (Scott et al., 2008), but during episodes of extreme global warming or mass extinction events that resulted in marine anoxic events, the return of sulfidic conditions to widespread areas of the deep sea would have caused 
seawater Mo depletion (Algeo, 2004). While it is not possible to directly extrapolate from the physiology of modern organisms to those of their ancestors, studying the Mo (and other trace metal) requirements of modern microbes living in environments with scarce Mo can provide us with a possible analogue to ancient ecosystems.

\section{ACKNOWLEDGMENTS}

This work was supported by funding from the NASA Astrobiology Institute, a NSF Graduate Research Fellowship (Geosciences-Geochemistry \#2006038382), an Arizona State University (ASU) Graduate and Professional Student Association Research Grant, a Grant-in-Aid of Research (\#G200810150320) from Sigma Xi The Scientific Research Society, and a Lewis and

\section{REFERENCES}

Achterberg, E. P., van den Berg, C. M. G., Boussemart, M., and Davison, W. (1997). Speciation and cycling of trace metals in Esthwaite Water: a productive English lake with seasonal deep-water anoxia. Geochim. Cosmochim. Acta 61, 5233-5253.

Algeo, T. J. (2004). Can marine anoxic events draw down the trace element inventory of seawater? Geology 32, 1057-1060.

Anbar, A. D., and Knoll, A. H. (2002). Proterozoic ocean chemistry and evolution: a bioinorganic bridge? Science 297, 1137-1142.

Anderson, A. J., and Spencer, D. (1949). Molybdenum and sulfur in symbiotic nitrogen fixation. Nature 164, 273-274.

Anderson, A. J., and Spencer, D. (1950). Molybdenum in nitrogen metabolism of legumes and non-legumes. Aust. J. Biol. Sci. 3, 414-430.

Arnon, D. I., Ichioka, P. S., Wessel, G., Fujiwara, A., and Wolley, J. T. (1955). Molybdenum in relation to nitrogen metabolism I. Assimilation of nitrate nitrogen by Scenedesmus. Physiol. Plant. 8, 538-551.

Arnon, D. I., and Stout, P. R. (1939). Molybdenum as an essential element for higher plants. Plant Physiol. 14, 599-602.

Attridge, E. M., and Rowell, P. (1997). Growth, heterocyst differentiation and nitrogenase activity in the cyanobacteria Anabaena variabilis and Anabaena cylindrica in response to molybdenum and vanadium. New Phytol. 135, 517-526.

Axler, R. P., Gersberg, R. M., and Goldman, C. R. (1980). Stimulation of nitrate uptake and photosynthesis by molybdenum in Castle Lake, California. Can. J. Fish. Aquat. Sci. 37, 707-712.

Axler, R. P., Gersberg, R. M., and Goldman, C. R. (1982). Inorganic nitrogen assimilation in a subalpine lake. Limnol. Oceangr. 27, 53-65.

Axler, R. P., and Goldman, C. R. (1981). Isotope tracer methods for investigations of nitrogen deficiency in Castle Lake, California. Water Res. 15, 627-632.

Axler, R. P., Redfield, G. W., and Goldman, C. R. (1981). The importance of regenerated nitrogen to phytoplankton productivity in a subalpine lake. Ecology 62, 345-354.

Axler, R. P., and Reuter, J. E. (1996). Nitrate uptake by phytoplankton and periphyton: whole-lake enrichments and mesocosm ${ }^{15} \mathrm{~N}$ experiments in an oligotrophic lake. Limnol. Oceangr. 41, 659-671.

Bachmann, R. W., and Goldman, C. R. (1964). The determination of microgram quantities of molybdenum in natural waters. Limnol. Oceanogr. 9, 143-146.

Balistrieri, L. S., Murray, J. W., and Paul, B. (1994). The geochemical cycling of trace elements in a biogenic meromictic lake. Geochim. Cosmochim. Acta 58, 3993-4008.

Barron, A. R., Wurzburger, N., Bellenger, J. P., Wright, S. J., Kraepiel, A. M. L., and Hedin, L. O. (2009). Molybdenum limitation of asymbiotic nitrogen fixation in tropical forest soils. Nat. Geosci. 2, 42-45.

Becking, J. H. (1961a). Molybdenum and symbiotic nitrogen fixation by alder (Alnus glutinosa Gaertn.). Nature 192, 1204-1205.

Becking, J. H. (1961b). A requirement of molybdenum for the symbiotic nitrogen fixation in alder (Alnus glutinosa Gaertn.). Plant Soil 15, 217-227.

Bellenger, J. P., Wichard, T., Kustka, A. B., and Kraepiel, A. M. (2008). Uptake of molybdenum and vanadium by a nitrogen-fixing soil bacterium using siderophores. Nat. Geosci. 1, 243-246.

Clark Astrobiology Field Research Grant from the American Philosophical Society and the NASA Astrobiology Institute. We thank Rene Henery, Hilairy Hartnett, and the two reviewers for critical readings and helpful suggestions for improvement of the manuscript, Rene Henery for coordination of field work, and Ariel Anbar, John Berges, Michael Brett, James Elser, Nancy Grimm, Mirta Teichberg, and David Wynne for helpful discussions. Megan Kelly provided field assistance, and Katie Noonan and Marcia Kyle aided with equipment transport. Members of the Castle Lake Long-Term Research Program (Jacquie Brownstein, Brooke Eustis, Marcy Kamerath, and Lauren Roaldson) aided with data collection where noted. Carina Arrua, Gwyneth Gordon, Marcia Kyle, and Natasha Zolotova helped with sample analysis at ASU.

Bellenger, J. P., Wichard, T., Xu, Y., and Kraepiel, A. M. L. (2011). Essential metals for nitrogen fixation in a free living $\mathrm{N}_{2}$ fixing bacterium: chelation, homeostasis and high use efficiency. Environ. Microbiol. 13, 1395-1411.

Bergman, B., Gallon, J. R., Rai, A. N., and Stal, L. J. (1997). $\mathrm{N}_{2}$ fixation by non-heterocystous cyanobacteria. FEMS Microbiol. Rev. 19, 139-185.

Berman-Frank, I., Lundgren, P., and Falkowski, P. (2003). Nitrogen fixation and photosynthetic oxygen evolution in cyanobacteria. Res. Microbiol. 154, 157-164.

Betancourt, D. A., Loveless, T. M., Brown, J. W., and Bishop, P. E. (2008). Characterization of diazotrophs containing Moindependent nitrogenases, isolated from diverse natural environments. Appl. Environ. Microbiol. 74, 3471-3480.

Bortels, H. (1930). Molybdan als Katalysator bei der biologischen Stickstoffbindung. Arch. Mikrobiol. 1, 333-342.

Bortels, H. (1940). Über die Bedeutung des Molybdands für stickstoffbindende Nostocaceen. Arch. Mikrobiol. 11, 155-186.

Boyd, E., Anbar, A., Miller, S., Hamilton, T., Lavin, M., and Peters, J. (2011). A late methanogen origin for molybdenum-dependent nitrogenase. Geobiology 9, 221-232.

Bradford, G. R., Bair, F. L., and Hunsaker, V. (1968). Trace and major element content of 170 High Sierra lakes in California. Limnol. Oceanogr. 13, 526-530.

Chappaz, A., Gobeil, C., and Tessier, A. (2008). Geochemical and anthropogenic enrichments of Mo in sediments from perennially oxic and seasonally anoxic lakes in Eastern Canada. Geochim. Cosmochim. Acta 72, 170-184.
CLEREP. (2011). "Castle Lake Environmental Research and Education Program; Chandra, S. (PI)" (University of Nevada, Reno and University of California, Davis), Available online at: http://www.castlelake.ucdavis.edu

Cole, J. J., Howarth, R. W., Nolan, S. S., and Marino, R. (1986). Sulfate inhibition of molybdate assimilation by planktonic algae and bacteria: some implications for the aquatic nitrogen cycle. Biogeochemistry 2, 179-196.

Cole, J. J., Lane, J. M., Marino, R., and Howarth, R. W. (1993). Molybdenum assimilation by cyanobacteria and phytoplankton in freshwater and salt water. Limnol. Oceanogr. 38, 25-35.

Collier, R. W. (1985). Molybdenum in the northeast Pacific Ocean. Limnol. Oceangr. 30, 1351-1354.

Cowgill, U. M. (1977). "The molybdenum cycle in Linsley Pond, North Branford, Connecticut," in Molybdenum in the Environment, eds W. R. Chapell and K. K. Peterson (New York, NY: Marcel Dekker), 705-723.

Dekas, A., Poretsky, R. S., and Orphan, V. J. (2009). Deep-sea archaea fix and share nitrogen in methaneconsuming microbial consortia. Science 326, 422-426.

Dellwig, O., Beck, M., Lemke, A., Lunau, M., Kolditz, K., Schnetger, B., and Brumsack, H. J. (2007). Non-conservative behaviour of molybdenum in coastal waters: coupling geochemical, biological, and sedimentological processes. Geochim. Cosmochim. Acta 71, 2745-2761.

Dortch, Q. (1990). The interaction between ammonium and nitrate uptake in phytoplankton. Mar. Ecol. Prog. Ser. 61, 183-201.

Dumont, H. J. (1972). The biological cycle of molybdenum in 
relation to primary production and waterbloom formation in a eutrophic pond. Int. Ver. Theor. Angew. Limnol. 18, 84-92.

Eady, R. R. (1996). Structure-function relationships of alternative nitrogenases. Chem. Rev. 96, 3013-3030.

Erickson, B. E., and Helz, G. R. (2000). Molybdenum(VI) speciation in sulfidic waters: stability and lability of thiomolybdates. Geochim. Cosmochim. Acta 64, 1149-1158.

Evans, J. C., and Prepas, E. E. (1997). Relative importance of iron and molybdenum in restricting phytoplankton biomass in high phosphorus saline lakes. Limnol. Oceanogr. 42, 461-472.

Fay, P., and Vasconcelos, L. (1974). Nitrogen metabolism and ultrastructure in Anabaena cylindrica. 2. Effect of molybdenum and vanadium. Arch. Microbiol. 99, 221-230.

Fenske, D., Gnida, M., Schneider, K., Meyer-Klaucke, W., Schemberg, J., Henschel, V., Meyer, A. K., Knochel, A., and Müller, A. (2005). A new type of metalloprotein: the Mo storage protein from Azotobacter vinelandii contains a polynuclear molybdenum-oxide cluster. ChemBioChem 6, 405-413.

Fogg, G. E., and Wolfe, M. (1954). The nitrogen metabolism of bluegreen algae (Myxophyceae). Symp. Soc. Gen. Microbiol. 4, 99-125.

Gersberg, R. M., Axler, R. P., Krohn, K., Peek, N., and Goldman, C. R. (1978). Nitrate uptake in phytoplankton: measurements utilizing the radioisotope, N-13. Verh. Int. Verein. Limnol. 20, 388-392.

Glass, J. B. (2011). Molybdenum Biogeochemistry in an Evolutionary Context: Nitrogen Assimilation, Microbial Storage and Environmental Budgets. Ph.D. thesis, Arizona State University.

Glass, J. B., Wolfe-Simon, F., and Anbar, A. D. (2009). Coevolution of metal availability and nitrogen assimilation in cyanobacteria and algae. Geobiology 7, 100-123.

Glass, J. B., Wolfe-Simon, F., Elser, J. J., and Anbar, A. D. (2010). Molybdenum-nitrogen co-limitation in freshwater and coastal heterocystous cyanobacteria. Limnol. Oceanogr. 55, 667-676.

Goldman, C. R. (1960). Molybdenum as a factor limiting primary productivity in Castle Lake, California. Science 132, 1016-1017.

Goldman, C. R. (1964). Primary productivity and micro-nutrient limiting factors in some North American and New Zealand lakes. Verh. Int. Verein. Limnol. 15, 365-374.
Goldman, C. R. (1966). "Molybdenum as an essential micronutrient and useful watermass marker in Castle Lake, California," in Proceedings of an International Biological Programme Symposium, eds $\mathrm{H}$. L. Golterman and R. S. Clymo (Amsterdam and Nieuwersluis, Netherlands), 229-238.

Goldman, C. R. (1972). "The role of minor nutrients in limiting the productivity of aquatic ecosystems," in Nutrients and Eutrophication: The Limiting-Nutrient Controversy, American Society of Limnology and Oceanography Special Symposia, No. 1, ed G. E. Likens (Lawrence, Kansas), 21-33.

Groth, P. (1971). Investigations of some trace elements in lakes. Arch. Hydrobiol. 68, 305-375.

Gupta, U. C. (ed.). (1997). Molybdenum in Agriculture. Cambridge, UK: Cambridge University Press.

Helz, G. R., Bura-Nakic, E., Mikac, N., and Ciglenecki, I. (2011). New model for molybdenum behavior in euxinic waters. Chem. Geol. 284, 323-332.

Helz, G. R., Miller, C. V., Charnock, J. M., Mosselmans, J. F. W., Pattrick, R. A. D., Garner, C. D., and Vaughan, D. J. (1996). Mechanism of molybdenum removal from the sea and its concentration in black shales: EXAFS evidence. Geochim. Cosmochim. Acta 60, 3631-3642.

Hewitt, E. J., and Jones, E. W. (1947). The production of molybdenum deficiency in sand culture with special reference to tomato and Brassica crops. J. Hortic. Sci. Biotechnol. 23, 254-269.

Hinton, S. M., and Merritt, B. (1986). Purification and characterization of a molybdenum-pterin-binding protein (Mop) in Clostridium pasteurianum W5. J. Bacteriol. 168, 688-693.

Howarth, R. W., and Cole, J. J. (1985). Molybdenum availability, nitrogen limitation, and phytoplankton growth in natural waters. Science 229, 653-655.

Howarth, R. W., Marino, R., and Cole, J. J. (1988). Nitrogen fixation in freshwater, estuarine, and marine ecosystems. 2. Biogeochemical controls. Limnol. Oceangr. 33, 688-701.

Hungate, B. A., Stiling, P. D., Dijkstra, P., Johnson, D. W., Ketterer, M. E., Hymus, G. J., Hinkle, C. R., and Drake, B. G. (2004). $\mathrm{CO}_{2}$ elicits long-term decline in nitrogen fixation. Science 304, 1291.

Ichioka, P. S., and Arnon, D. I. (1955). Molybdenum in relation to nitrogen metabolism II. Assimilation of ammonia and urea without molybdenum by Scenedesmus. Physiol. Plant. 8, 552-560.

Jacob, R., and Lind, O. (1977) The combined relationship of temperature and molybdenum concentration to nitrogen fixation by Anabaena cylindrica. Microb. Ecol. 3, 205-217.

Jassby, A. D., and Goldman, C. R. (1974). A quantitative measure of succession rate and its application to the phytoplankton of lakes. Am. Nat. 108, 688-693.

Johannesson, K. H., Lyons, W. B., Graham, E. Y., and Welch, K. A. (2000). Oxyanion concentrations in eastern Sierra Nevada rivers3. Boron, molybdenum, vanadium, and tungsten. Aquat. Geochem. 6, 19-46.

Kuroda, P. K., and Sandell, E. B. (1954). Geochemistry of molybdenum. Geochim. Cosmochim. Acta 6 , 35-63.

Liermann, L. J., Guynn, R. L., Anbar, A., and Brantley, S. L. (2005). Production of a molybdophore during metal-targeted dissolution of silicates by soil bacteria. Chem. Geol. 220, 285-302.

Lithner, G., Borg, H., Ek, J., Fröberg, E., Holm, K., Johansson, A.-M., Kärrhage, P., Rosén, G., and Söderström, M. (2000). The turnover of metals in a eutrophic and an oligotrophic lake in Sweden. Ambio 29, 217-229.

Loeb, S. L., and Reuter, J. E. (1981). The epilithic periphyton community: a five-lake comparative study of community productivity, nitrogen metabolism and depth-distribution of standing crop. Verh. Int. Verein. Limnol. 21, 346-352.

Loneragan, J., and Arnon, D. (1954). Molybdenum in the growth and metabolism of Chlorella. Nature 174, 459.

Magyar, B., Moor, H. C., and Sigg, L. (1993). Vertical distribution and transport of molybdenum in a lake with a seasonally anoxic hypolimnion. Limnol. Oceangr. 38, 521-531.

Marino, R., Howarth, R. W., Chan, F., Cole, J. J., and Likens, G. E. (2003). Sulfate inhibition of molybdenum-dependent nitrogen fixation by planktonic cyanobacteria under seawater conditions: a non-reversible effect. Hydrobiologia 500, 277-293.

Marino, R., Howarth, R. W. Shamess, J., and Prepas, E. (1990). Molybdenum and sulfate as controls on the abundance of nitrogen-fixing cyanobacteria in saline lakes in Alberta. Limnol. Oceanogr. 35, 245-259.
Nicholas, D. J. D., and Nason, A. (1954). Molybdenum and nitrate reductase II. Molybdenum as a constituent of nitrate reductase. J. Biol. Chem. 207, 353-360.

Nicholas, D. J. D., Nason, A., and McElroy, W. D. (1954). Molybdenum and nitrate reductase I. Effect of molybdenum deficiency on the Neurospora enzyme. J. Biol. Chem. 207, 341-352.

Nuester, J., Vogt, S., Newville, M., Kustka, A. B., and Twining, B. S. (2012). The unique biochemical signature of the marine diazotroph Trichodesmium. Front. Microbiol. 3:1-15. doi: 10.3389/fmicb. 2012 . 00150

Paerl, H. W., Crocker, K. M., and Prufert, L. E. (1987). Limitation of $\mathrm{N}_{2}$ fixation in coastal marine waters - relative importance of molybdenum, iron, phosphorus, and organic matter availability. Limnol. Oceangr. 32, 525-536.

Pau, R. N. (2004). "Molybdenum uptake and homeostasis," in Genetics and Regulation of Nitrogen Fixation in Free-Living Bacteria, eds W. Klipp, B. Masepohl, J. R. Gallon, and W. E. Newton (Netherlands: Springer), 225-256.

Paulsen, D. M., Paerl, H. W., and Bishop, P. E. (1991). Evidence that molybdenum-dependent nitrogen fixation is not limited by high sulfate concentrations in marine environments. Limnol. Oceangr. 36, 1325-1334.

Peschek, G. A. (1979). Nitrate and nitrite reductase and hydrogenase in Anacystis nidulans grown in $\mathrm{Fe}$ - and Mo-deficient media. FEMS Microbiol. Lett. 6, 371-374.

Pienkos, P. T., and Brill, W. J. (1981). Molybdenum accumulation and storage in Klebsiella pneumoniae and Azotobacter vinelandii. J. Bacteriol. 145, 743.

Priscu, J. C., Axler, R. P., and Goldman, C. R. (1985). Nitrogen metabolism of the shallow and deep-water phytoplankton in a subalpine lake. Oikos 45, 137-147.

Raven, J. A. (1988). The iron and molybdenum use efficiencies of plant growth with different energy, carbon and nitrogen sources. New Phytol. 109, 279-287.

Raymond, J., Siefert, J. L., Staples, C. R., and Blankenship, R. E. (2004). The natural history of nitrogen fixation. Mol. Biol. Evol. 21, 541-554.

Reuter, J. E., and Axler, R. P. (1988). A comparison of methodologies used to measure nutrient uptake by periphyton. Verh. Int. Verein. Limnol. 23 , 915-918. 
Reuter, J. E., and Axler, R. P. (1992). Physiological characteristics of inorganic nitrogen uptake by spatially separate algal communities in a nitrogen deficient lake. Freshwater Biol. 27, 227-236.

Reuter, J. E., Loeb, S. L., Axler, R. P., Carlton, R. G., and Goldman, C. R. (1985). Transformations of nitrogen following an epilimnetic nitrogen fertilization in Castle Lake, California. 1. Epilithic periphyton responses. Arch. Hydrobiol. 102, 425-433.

Robson, R. L., Eady, R. R., Richardson, T. H., Miller, R. W., Hawkins, M., and Postgate, J. R. (1986). The alternative nitrogenase of Azotobacter chroococcum is a vanadium enzyme. Nature 322, 388-390.

Romero, I. C., Klein, N. J., Barada, L., Vo, J., Liss, A. M., Cutter, L., Gunderson, T., Tiahlo, M., Glass, J. B., Sañudo-Wilhelmy, S. A., and Capone, D. G. (2011). "Trace metal co-limitation controls on nitrogen fixation in lakes with varying trophic status," in ASLO Aquatic Sciences Meeting, (San Juan, Puerto Rico).

Sanders, F. (1976). An Investigation of Carbon Flux in the Sediment of Castle Lake. Ph.D. thesis, University of California Davis.

Schoepp-Cothenet, B., Van Lis, R., Philippot, P., Magalon, A., Russell, M. J., and Nitschke, W. (2012). The ineluctable requirement for the trans-iron elements molybdenum and/or tungsten in the origin of life. Sci. Rep. 2, 263.

Schüttelkopf, A. W., Harrison, J. A., Boxer, D. H., and Hunter, W. N. (2002). Passive acquisition of ligand by the MopII molbindin from Clostridium pasteurianum: structures of apo and oxyanionbound forms. J. Biol. Chem. 277, 15013-15020.

Scott, C., Lyons, T. W., Bekker, A., Shen, Y., Poulton, S. W., Chu, X., and Anbar, A. D. (2008). Tracing the stepwise oxygenation of the Proterozoic ocean. Nature 452, 456-459.

Self, W. T., Grunden, A. M., Hasona, A., and Shanmugam, K. T. (2001). Molybdate transport. Res. Microbiol. $152,311-321$.

Sigel, A., and Sigel, H. (2002). Molybdenum and Tungsten: Their Roles in Biological Systems. New York, NY: Marcel Dekker.

Silvester, W. B. (1989). Molybdenum limitation of asymbiotic nitrogen fixation in forests of Pacific Northwest America. Soil Biol. Biochem. 21, 283-289.

Sohm, J. A., Webb, E. A., and Capone, D. G. (2011). Emerging patterns of marine nitrogen fixation. Nat. Rev. Microbiol. 9, 499-508.

Solomonson, L. P., Barber, M. J., Robbins, A. P., and Oaks, A. (1986). Functional domains of assimilatory NADH: nitrate reductase from Chlorella. J. Biol. Chem. 261, 11290-11294.

Sprent, J. I., and Raven, J. A. (1985). Evolution of nitrogen-fixing symbioses. Proc. R. Soc. Edinb. B Biol. Sci. 85, 215-237.

Steinberg, R. A. (1937). Role of molybdenum in the utilization of ammonium and nitrate nitrogen by Aspergillus niger. J. Agric. Res. 55, 891-902.

Sugawara, K., Okabe, S., and Tanaka, M. (1961). Geochemistry of molybdenum in natural waters (II). $J$. Earth Sci. 9, 114-128.

Tejada-Jimenez, M., Llamas, A., Sanz-Luque, E., Galvan, A., and Fernandez, E. (2007). A highaffinity molybdate transporter in eukaryotes. Proc. Natl. Acad. Sci. U.S.A. 104, 20126-20130.

ter Steeg, P. F., Hanson, P. J., and Paerl, H. W. (1986). Growth-limiting quantities and accumulation of molybdenum in Anabaena oscillarioides (Cyanobacteria). Hydrobiologia 140, 143-147.

Thiel, T., Pratte, B., and Zahalak, M. (2002). Transport of molybdate in the cyanobacterium Anabaena variabilis ATCC 29413. Arch. Microbiol. 179, 50-56.

Tuit, C., Waterbury, J., and Ravizza, G. (2004). Diel variation of molybdenum and iron in marine diazotrophic cyanobacteria. Limnol. Oceangr. 49, 978-990.

Vega, J. M. A., Herrera, J., Aparicio, P. J., Paneque, A., and Losada, M. (1971). Role of molybdenum in nitrate reduction by Chlorella. Plant Physiol. 48, 294-299.

Vitousek, P. M., and Howarth, R. W. (1991). Nitrogen limitation on land and sea: how can it occur? Biogeochemistry 13, 87-115.

Vorlicek, T. P., and Helz, G. R. (2002). Catalysis by mineral surfaces: implications for Mo geochemistry in anoxic environments. Geochim. Cosmochim. Acta 66, 3679-3692.

Vorlicek, T. P., Kahn, M. D., Kasuya, Y., and Helz, G. R. (2004). Capture of molybdenum in pyrite-forming sediments: role of ligand-induced reduction by polysulfides. Geochim Cosmochim. Acta 68, 547-556.

Walker, J. (1953). Inorganic micronutrient requirements of Chlorella. I. Requirements for calcium (or strontium), copper, and molybdenum. Arch. Biochem. Biophys. 46 1-11.

Walker, R. B. (1948). Molybdenum deficiency in serpentine barren soils. Science 108, 473-475.

Wallen, D. G., and Cartier, L. D. (1975) Molybdenum dependence, nitrate uptake and photosynthesis of freshwater plankton algae. J. Phycol. 11, 345-349.

Walve, J., and Larsson, U. (2007). Blooms of Baltic Sea Aphanizomenon sp. (Cyanobacteria) collapse after internal phosphorus depletion. Aquat. Microb. Ecol. 49, 57-69.

Wang, D., Aller, R. C., and SañudoWilhelmy, S. A. (2011). Redox speciation and early diagenetic behavior of dissolved molybdenum in sulfidic muds. Mar. Chem. 125, 101-107.

Wang, D., Aller, R. C., and SañudoWilhelmy, S. A. (2009). A new method for the quantification of different redox-species of molybdenum (V and VI) in seawater. Mar. Chem. 113, 250-256.

Wasylenki, L. E., Anbar, A. D., Liermann, L. J., Mathur, R., Gordon, G. W., and Brantley, S. L. (2007). Isotopic fractionation during microbial metal uptake measured by MC-ICP-MS. J. Anal. At. Spectrom. 22, 905-910.

Wetzel, R. G. (2001). Limnology: Lake and River Ecosystems, 3rd Edn. San Diego, CA: Academic Press.

Wolfe, M. (1954). The effect of molybdenum upon the nitrogen metabolism of Anabaena cylindrica. II. A more detailed study of the action of molybdenum in nitrate assimilation. Ann. Bot. Lond. 18, 309-325.

Wurtsbaugh, W. A. (1988). Iron, molybdenum and phosphorus limitation of $\mathrm{N}_{2}$ fixation maintains nitrogen deficiency of plankton in the Great Salt Lake drainage (Utah, USA). Verh. Int. Verein Limnol. 23, 121-130.

Wurzburger, N., Bellenger, J. P., Kraepiel, A. M. L., and Hedin, L. O. (2012). Molybdenum and phosphorus interact to constrain asymbiotic nitrogen fixation in tropical forests. PLoS ONE 7:e33710. doi: 10.1371/journal.pone.0033710
Zahalak, M., Pratte, B., Werth, K. J., and Thiel, T. (2004). Molybdate transport and its effect on nitrogen utilization in the cyanobacterium Anabaena variabilis ATCC 29413. Mol. Microbiol. 51, 539-549.

Zehr, J. P., Axler, R. P., and Goldman, C. R. (1985). Heterotrophic mineralization of amino acid nitrogen in subalpine Castle Lake, California. Mar. Chem. 16, 343-350.

Zerkle, A. L., House, C. H., Cox, R. P., and Canfield, D. E. (2006). Metal limitation of cyanobacterial $\mathrm{N}_{2}$ fixation and implications for the Precambrian nitrogen cycle. Geobiology 4, 285-297.

Zerkle, A. L., Scheiderich, K., Maresca, J. A., Liermann, L. J., and Brantley, S. L. (2011). Molybdenum isotope fractionation by cyanobacterial assimilation during nitrate utilization and $\mathrm{N}_{2}$ fixation. Geobiology 9 , 94-106.

Zhang, Y., and Gladyshev, V. N. (2008). Molybdoproteomes and evolution of molybdenum utilization. J. Mol. Biol. 379, 881-899.

Zhang, Y., and Gladyshev, V. N. (2010). General trends in trace element utilization revealed by comparative genomic analyses of $\mathrm{Co}, \mathrm{Cu}, \mathrm{Mo}$, $\mathrm{Ni}$ and Se. J. Biol. Chem. 285, 3393-3405.

Conflict of Interest Statement: The authors declare that the research was conducted in the absence of any commercial or financial relationships that could be construed as a potential conflict of interest.

Received: 30 June 2012; accepted: 24 August 2012; published online: 13 September 2012.

Citation: Glass JB, Axler RP, Chandra S and Goldman CR (2012) Molybdenum limitation of microbial nitrogen assimilation in aquatic ecosystems and pure cultures. Front. Microbio. 3:331. doi: 10.3389/fmicb.2012.00331

This article was submitted to Frontiers in Aquatic Microbiology, a specialty of Frontiers in Microbiology.

Copyright (c) 2012 Glass, Axler, Chandra and Goldman. This is an open-access article distributed under the terms of the Creative Commons Attribution License, which permits use, distribution and reproduction in other forums, provided the original authors and source are credited and subject to any copyright notices concerning any third-party graphics etc. 